Article

\title{
Socioeconomic Perspectives on Household Chestnut Fruit Utilization and Chestnut Blight Prevention Efforts in Turkey
}

\author{
Taner Okan ${ }^{1}$, Coşkun Köse ${ }^{2, *}$ and Jeffrey R. Wall ${ }^{3}$ \\ 1 Faculty of Forestry, Department of Forestry Economics, Istanbul University, Bahçeköy, İstanbul 34473, \\ Turkey; tokan@istanbul.edu.tr \\ 2 Faculty of Forestry, Department of Forest Biology and Wood Protection Technology, Istanbul University, \\ Bahçeköy, İstanbul 34473, Turkey \\ 3 Department of Natural Resources, Cornell University, 111 Fernow Hall, Ithaca, NY 14850, USA; \\ jrw297@cornell.edu \\ * Correspondence: ckose@istanbul.edu.tr; Tel.: +90-212-338-2400 (ext. 25371)
}

Academic Editor: Audrey L. Mayer

Received: 24 March 2017; Accepted: 12 May 2017; Published: 15 May 2017

\begin{abstract}
Exotic pathogens, within the center of genetic diversity for the species, compromise European chestnut populations in Turkey. In Turkey today, the species is of tremendous economic, ecological and cultural importance. At this time of severe exotic pathogenic pressure on a highly-valued forest species, we ask, how does awareness of diseases and treatments as well as value for chestnut trees affect the efforts of households to manage pests and diseases of chestnut trees in Turkey? We conducted 96 surveys in 34 villages in 10 provinces across Turkey to investigate awareness of diseases and other challenges to the chestnut population, chestnut harvesting habits, family value for chestnuts and efforts to mitigate pest and disease pressure. We analyze our results using cluster and regression analysis. Our results show that based on analysis of all observed characteristics, our research sites in Turkey break cleanly into groups based on production level. Further, results demonstrate significant correlation between amount of chestnut-derived income and awareness of pests and diseases as well as the likelihood of households enacting disease mitigation measures. These results also demonstrate correlation between observed awareness of diseases and pests and the likelihood of households enacting disease mitigation measures.
\end{abstract}

Keywords: Castanea sativa; non-wood forest products; forest disease mitigation; household economy

\section{Introduction}

Chestnut (Castanea sativa Mill.) populations in Turkey are enduring exotic pathogen pressure across the species range, challenging chestnut-dependent livelihoods everywhere in the country. There is a deep and uninterrupted history of chestnut maintenance in the region. In 400 B.C., the Greek historian Xenophon documented the prevalence of this nut and chestnut-bread in the local diet [1]. Today, chestnut forests provide a variety of wood and non-wood forest products (NWFP). Important NWFP include flowers, fruit and chestnut honey, and also some edible mushrooms which grow only under chestnut trees [2]. Chestnuts' general distribution in Turkey includes the Marmara, Aegean and Black Sea regions $[3,4]$. The tree is cultivated at varying degrees of intensity in all of these regions.

In order of their arrival, chestnut pathogens are ink disease (caused by oomycete Phytophthora cambivora (Petri) Buisman) [5], chestnut blight (caused by the fungus Cryphonectria parasitica (Murrill) Barr) [6] and, more recently, Chestnut Gall-wasp, (caused by the wasp species Dryocosmus kuriphilus 
Yasumatsu) [7]. The chestnut blight fungus, which has been present in Turkey since the late 1960s, is considered by experts to be the most impactful of these. Most research into chestnut blight mitigation focuses on a biological control known as applied hypovirulence [8,9]. Though shown to be effective, biological control cannot be performed by smallholders. What can be implemented by smallholders and forest officers are simple sanitation measures such as limb removal and destruction, and elimination of dead and dying vegetative material [10]. Though some studies in the European context have looked at dynamics of land-owner interest in biological control measures [11,12], very few studies have investigated the effects of small-scale household blight mitigation efforts [13].

The origins of the chestnut blight fungus are in East Asia. Its spread in North America and Europe is attributed to the importation of infected timber and nursery stock [14]. Chestnut blight caused by C. parasitica has been spreading in Turkey since 1967, producing damage to chestnut stands and orchards [15]. Disease severity in the highly productive areas of western Turkey increased sharply beginning in the 1990s. National production decreased from 90,000 tons in 1988 to below 50,000 tons in the early 2000s. Average production between 1994 and 2014 was 57,000 tons [16]. Adding to the complexity of the epidemiological environment, the natural presence of what is known as hypovirulence, has been observed throughout Turkey [17,18]. Hypovirulence occurs when a naturally occurring virus, also originally from East Asia, infects the chestnut blight fungus and diminishes its virulence. Currently, there is no consensus on where or the degree to which hypovirulence is mediating blight severity.

Another dynamic is present in Turkey, such as in Sinop, where the economic emigration of young people to cities and to Europe has resulted in an older average resident population $[19,20]$. The Food and Agricultural Organization of the United Nations (FAO) report on chestnut blight and its management in Turkey [10] goes so far as to state that outmigration from Sinop was caused by chestnut blight. Out-migration of younger populations is also the reason why physical difficulties are one of the problems reported by Chamber of Agriculture in Zonguldak [21]. It is a commonly repeated notion that NWFP are not valued enough in Turkey and that this is a partial explanation of the challenges to rural viability in forest dominated rural areas [22]. This represents a critical conundrum; if NWFP were valuable, people would emigrate less and if there were more representative demographics in rural forested Turkey, utilization of NWFP would be more robust. Our research represents a preliminary exploration of these dynamics on the case of a single important forest species.

At this time of severe exotic pathogenic pressure on a highly-valued forest species $[23,24]$ we ask, how does household awareness of diseases and treatments for chestnut and value affect efforts of households to manage pests and diseases of chestnut trees in Turkey? We conducted research across Turkey to investigate geographical variations in the relations between the (1) awareness of treatments on chestnut trees and tree populations; (2) actions taken to maintain tree populations; (3) chestnut harvesting habits; and (4) the value associated with the trees, all in a context of disease pressure across a great variety of cultural and geographic space in Turkey. The disease severity is similarly variable across space. Disease severity appears to be highest in the eastern and then western Black Sea region [13]. Our investigation into awareness, practices and value in this context can provide insight into similar contexts where ecological hazards inherent to globalization are driving into local contexts and challenging local ecological maintenance.

\section{Material and Methods}

We performed field research during the summers of 2015 and 2016 in 34 village sites in the eastern and western Black Sea, Marmara and Aegean regions. Our activities were completed in a total of ten sites with a total of 96 households. Village sites were selected in the provinces of İstanbul, Zonguldak, Sinop, Artvin, Rize, Trabzon, Çanakkale, Aydın, İzmir and Bursa based on the known range of sweet chestnut and on the suggestions of the Turkish National Directorate of Forestry regarding zones of livelihood importance for the tree (Figure 1). 


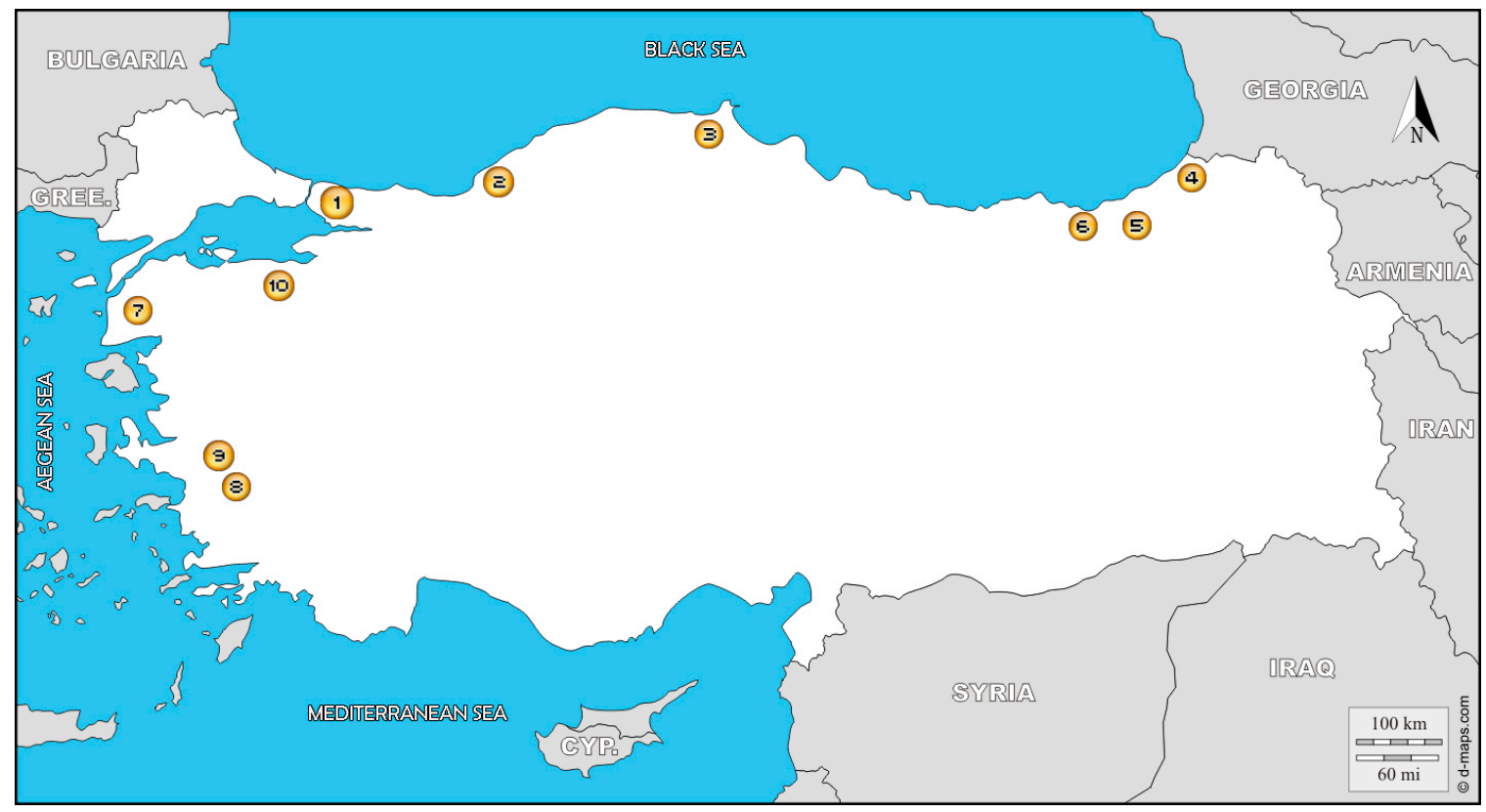

Figure 1. Turkey and sites investigated by the research team. 1: Şile, 2: Zonguldak, 3: Sinop, 4: Artvin, 5: Rize, 6: Trabzon, 7: Çanakkale, 8: Aydın, 9: İzmir, 10: Bursa. Image source: d-maps.com.

We acquired informed consent from all research participants prior to research activities. Surveys were conducted in a place of the participants choosing, often in the home garden or in the local café. Our socioeconomic survey was designed to learn about (1) awareness of households related to problems and diseases for chestnut utilization; (2) applied disease prevention practices especially for chestnut blight; (3) expenditures for preventing chestnut blight; (4) harvest customs; (5) harvest quantity; and (6) harvest related income. In addition to these, we asked two open-ended questions to gather opinions about the importance of chestnut harvesting, and to find out whether there was any other issue related to chestnut collecting.

We used linear regression analysis to explore the relationship between household awareness of pests and diseases (as counts) and the presence or absence of reported acts of disease control. We also explored whether and how harvest quantity was related to the presence or absence of reported acts of disease control, awareness of diseases and the number of individuals reported to partake in the harvest activities. For each of these factors, mean household values and percentages were employed in regression analysis. We also used multiple linear regression analysis to show the relative effect of both harvest amount and awareness of diseases on the presence or absence of applied control practices. Moreover, hierarchical cluster analysis [25] was performed to classify sites into groups according to their mean harvest quantity, percentage of respondents that applied control, the average number of known diseases and the average income.

\section{Results}

\subsection{The Results of Interviews with Households}

The main problems reported for chestnut trees were pest damage, transportation problems, lack of knowledge, public support and processing-storage facilities (Table 1). Diseases and pests were the most frequently reported problem for almost all sites, and included chestnut blight, ink disease, chestnut gall-wasp and chestnut fruit tortrix, respectively. Chestnut blight was the most mentioned one and generally described as dried or dying tree branches.

Interviewed households emphasized various other threats, and these differed by region (Table 1). For example, Hydro-electric Power Plants (HPP) were reported to be a factor in reduced productivity 
of chestnut forests through the eastern Black Sea region. In addition, Thermic Power Plants (TPP) and power grids are the highly-reported factors in Zonguldak. Intensive mining activities are said to threaten chestnut forest areas, while their dusts reportedly affect health of trees in Şile, İstanbul. Another problem for the households in Şile, located in proximity to two cities, is external pickers. Wildlife, especially wild boars, were reported to cause damages to yield in the Black Sea region (in Sinop, Trabzon, Rize and Artvin) and also in Aydın.

Households reported that only chestnut blight was the target of management measures. The households from the eastern Black Sea region reported no practices to prevent chestnut blight, while the other regions did. Cutting infected brunches is common for all sites for fighting diseases. In İstanbul, Zonguldak and Sinop, where 10-20\% report acts of disease control, only cutting infected branches is applied. In Çanakkale and Bursa, where $40-50 \%$ of the households report acts of disease control, infected branches are cut and Bordeaux mixture is applied as a spray. In Aydın and İzmir, where $90-100 \%$ of the households report acts of disease control, methods include cutting infected branches, application of Bordeaux mixture, juniper tar, sodium hypochlorite as well as aggressive removal of infected bark and cambium. Application of paste, mud packs and lime solution were recorded only in Aydın. Twenty percent of the households in Çanakkale and Bursa and $80 \%$ of the households in Aydın and İzmir invest money in controlling chestnut blight (Table 2).

The last part of our survey focused on harvest activities of households in different regions. Our interview results showed that chestnuts are generally collected by family members, relatives and/or neighbors, while laborers are only employed in Sinop, Aydın, İzmir, and Bursa (Table 3). The reported reasons of household motivation for chestnut harvest include income, food, tradition, and continuation of land ownership. Most households in the eastern Black Sea region do not sell fruit, but instead collect for home consumption. The households in İstanbul, Zonguldak, Sinop and Çanakkale earn money from chestnut sales as an additional income, and reserve some amount for their consumption. On the contrary, chestnut sales are the main income source for the households in Aydın, İzmir, and for many in Bursa. Accordingly, the highest production amount was reported in Aydın and İzmir, while the lowest amounts were reported in the eastern Black Sea region (Artvin, Rize and Trabzon). According to our survey, the most expensive chestnuts are in Sinop and Bursa, while the cheapest are in Zonguldak. Moreover, the chestnuts of Aydın have a Geographical Indication Protection (GIP) as an industrial property right. 
Table 1. Responses about the biggest problems facing the interviewees regarding chestnut picking. Responses arranged by percentages at site level (\%).

\begin{tabular}{|c|c|c|c|c|c|c|c|c|c|c|c|}
\hline Question & Answer & İstanbul & Zonguldak & Sinop & Artvin & Rize & Trabzon & Çanakkale & Aydın & İzmir & Bursa \\
\hline \multirow{12}{*}{ The biggest problems about chestnut picking } & Pest damages (\%) & 66 & 22 & 28 & 42 & 56 & 60 & 69 & 82 & 91 & 82 \\
\hline & Transportation (\%) & 7 & 22 & 9 & & & & & & & 9 \\
\hline & Lack of Knowledge (\%) & 0 & 9 & & & & & 23 & & & 9 \\
\hline & Lack of Public Support (\%) & 7 & 9 & & & & & 8 & & 9 & \\
\hline & Lack of Processing-Storage facilities (\%) & & 9 & 20 & & & & & 9 & & \\
\hline & Other Threats $(\%)$ & 20 & 29 & 43 & 48 & 44 & 40 & & 9 & & \\
\hline & Hydro-electric Power Plants & & & & + & + & + & & & & \\
\hline & Thermic Power Plants and Power grids & & + & & & & & & & & \\
\hline & Mining activities & + & & & + & & & & & & \\
\hline & Wildlife & & & + & + & + & + & & + & & \\
\hline & External Pickers & + & & & & & & & & & \\
\hline & Physical difficulties about harvesting & & + & + & & & & & & & \\
\hline \multirow{4}{*}{ Experienced or known pest damages } & Chestnut Blight (\%) & 43 & 71 & 77 & 100 & 100 & 100 & 64 & 48 & 50 & 63 \\
\hline & Ink disease $(\%)$ & 43 & & 15 & & & & 22 & 29 & 45 & 25 \\
\hline & Chestnut fruit tortrix (weevil) (\%) & 5 & 29 & & & & & 14 & 4 & & \\
\hline & Gall-wasp (\%) & 9 & & 8 & & & & & 19 & 5 & 12 \\
\hline
\end{tabular}

Note: "+" indicates the presence of other threats mentioned by interviewees.

Table 2. Responses regarding household application of control practices to prevent chestnut blight. Responses arranged by percentages at site level (\%).

\begin{tabular}{|c|c|c|c|c|c|c|c|c|c|c|c|}
\hline Question & Answer & İstanbul & Zonguldak & Sinop & Artvin & Rize & Trabzon & Çanakkale & Aydın & İzmir & Bursa \\
\hline \multirow{2}{*}{ Any control practices } & Yes $(\%)$ & 20 & 10 & 20 & 0 & 0 & 0 & 40 & 100 & 90 & 50 \\
\hline & No $(\%)$ & 80 & 90 & 80 & 100 & 100 & 100 & 60 & 0 & 10 & 50 \\
\hline \multirow{8}{*}{$\begin{array}{l}\text { Type of applied control practices (if any } \\
\text { control practices applied) }\end{array}$} & Removal of the infected branches & + & + & + & & & & + & + & + & + \\
\hline & Scraping the infected areas from trunks & & & & & & & & + & + & \\
\hline & Bordeaux mixture & & & & & & & + & + & + & + \\
\hline & Juniper tar & & & & & & & & + & + & \\
\hline & Sodium hypochloride & & & & & & & & + & + & \\
\hline & Paste & & & & & & & & + & & \\
\hline & Lime solution & & & & & & & & + & & \\
\hline & Mudpack (Soil Compress) & & & & & & & & + & & \\
\hline \multirow{2}{*}{$\begin{array}{l}\text { Control expenditures (if any control } \\
\text { practices applied) }\end{array}$} & Yes $(\%)$ & 0 & 0 & 0 & 0 & 0 & 0 & 20 & 80 & 80 & 20 \\
\hline & No $(\%)$ & 100 & 100 & 100 & 100 & 100 & 100 & 80 & 20 & 20 & 80 \\
\hline
\end{tabular}

Note: "+" indicates the presence of control practices type applied by interviewees. 
Table 3. Responses regarding harvest activities of households.

\begin{tabular}{|c|c|c|c|c|c|c|c|c|c|c|c|}
\hline Question & Answer & İstanbul & Zonguldak & Sinop & Artvin & Rize & Trabzon & Çanakkale & Aydın & İzmir & Bursa \\
\hline \multirow{3}{*}{ Who picks } & Family + Relatives & + & + & + & & + & + & + & + & + & + \\
\hline & Friends + Neighbours & + & & + & + & + & + & + & & & \\
\hline & Labors & & & + & & & & & + & + & + \\
\hline \multirow{5}{*}{ Motivation for harvest } & Income $^{1}$ & $\mathrm{~A}$ & A & $\mathrm{A}$ & $\mathrm{H}$ & $\mathrm{H}$ & $\mathrm{H}$ & A & $\mathrm{M}$ & M & M \\
\hline & Tradition & + & + & + & + & + & + & + & & & \\
\hline & Food & + & + & + & + & + & + & + & + & + & + \\
\hline & Maintain Ownership & & + & & & & & & & & \\
\hline & Activity & + & & & & & & & & & \\
\hline Average harvest quantities per household (kg) & & 116 & 855 & 1600 & 76 & 23 & 28 & 665 & 6350 & 6800 & 2595 \\
\hline
\end{tabular}

Notes: ${ }^{1}$ A: Additional income (including household consumption); M: Main income (including household consumption), H: Only household consumption; “" indicates the presence of who harvests chestnut fruits (family, neigbour etc.) 


\subsection{The Results of Regression Analysis}

The results of regression analysis exploring the relations between mean site reported acts of disease management, the number of known diseases, and harvest quantity are given in Figure 2. Correlation between the number of known diseases and percentage of households per site reporting acts of disease mitigation was insignificant $\left(\mathrm{R}^{2}=\right.$ and $\left.0.54, p>0.05\right)$. With other analyses, it was useful to remove the site of Şile, where the ratio of harvest to other factors was significantly affected by local disease pressure, eliminating the possibility of harvest activities. Barring Şile, correlation of average site reported disease control efforts and the number of known diseases was significant as shown in Figure $2 \mathrm{a}\left(\mathrm{R}^{2}=0.99 ; p<0.001\right)$. Figure $2 \mathrm{c}$ illustrates that awareness of diseases increases with harvest amount $\left(R^{2}=0.92, p<0.001\right)$. Figure $2 b$ illustrates the significant correlation between chestnut harvest quantities and percentage per site of households which report disease management measures $\left(R^{2}=0.87, p<0.001\right)$.

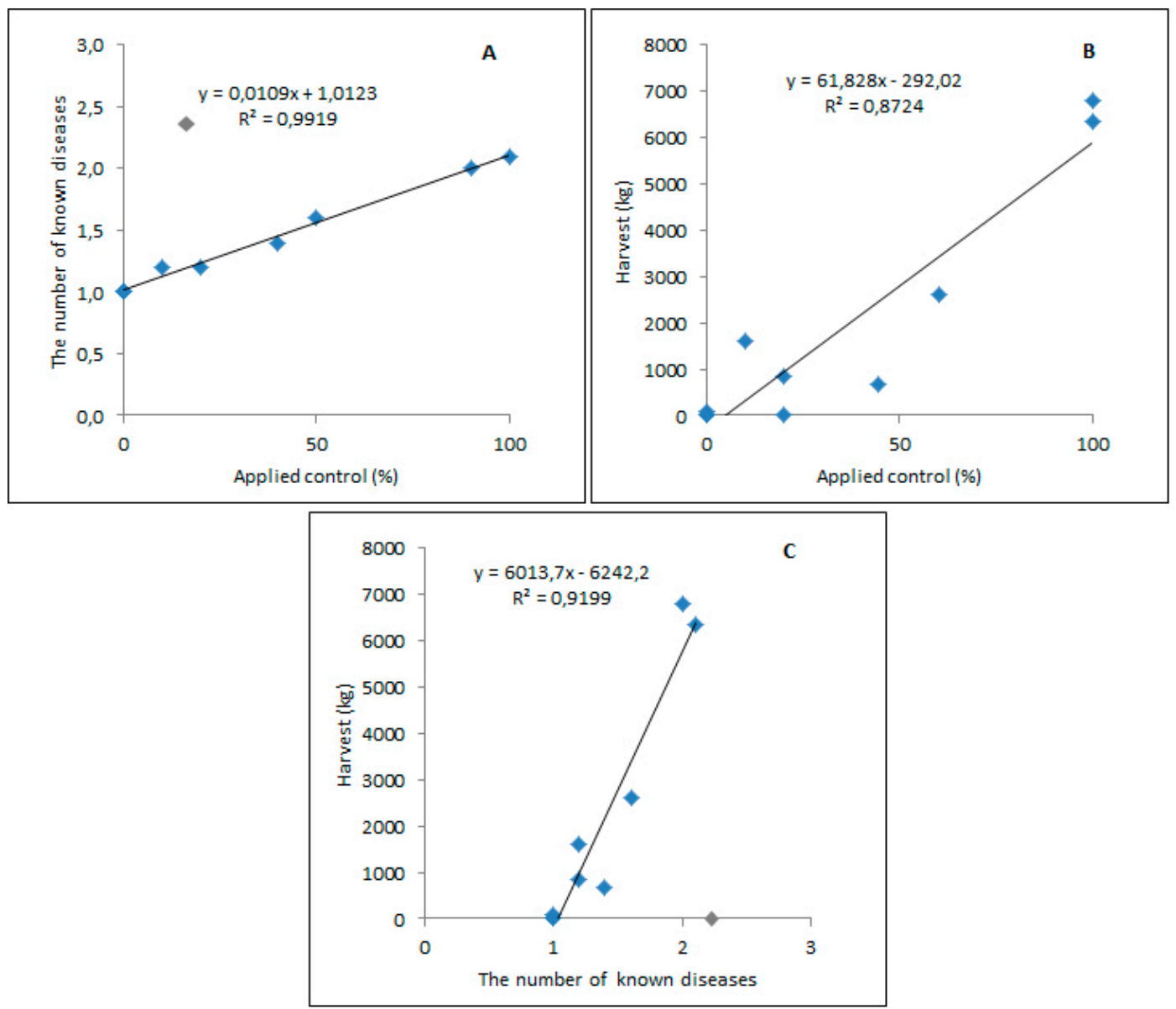

Figure 2. The results of regression analysis. (A) The relationship between the mean site percentage of the presence of reported acts of disease management and the number of known diseases. The gray rectangle represents the data from Şile, removed from the analysis. (B) The relationship between mean harvest quantity per household and mean site percentage of the presence of reported acts of applied control. (C) The relationship between mean harvest quantity per household and the number of known diseases. The gray rectangle represents the data from Şile, which is removed from the analysis.

Tables 4 and 5 show the results of multiple linear regression analysis of harvest amount and awareness on the dependent variable, i.e., applied control. This was performed with data that included data from Şile (Table 4) and with data that excluded data from Şile (Table 5). In both cases, awareness and harvest amount are observed to be significant. The relative significance of these factors is also 
illustrated by these results. Harvest amount is a more significant predictor of applied control in both analyses. Perhaps for the reasons discussed above, the exclusion of Şile rendered a higher R-squared value for the regression.

Table 4. Results of multiple linear regression analysis of harvest amount and awareness of disease effect on reported applied control using data which included the site of Şile.

\begin{tabular}{ccc}
\hline Factor & $\boldsymbol{t}$-Value & $\operatorname{Pr}(>|t|)$ \\
\hline Harvest & 5.582 & $2.33 \mathrm{e}-07^{* * *}$ \\
Awareness & 3.853 & $0.000214^{* * *}$ \\
Adjusted R Squared & & 0.4161 \\
\hline \multicolumn{2}{c}{ Note: ${ }^{* * *}$ indicates significant values $(p<0.001)}$.
\end{tabular}

Table 5. Results of multiple linear regression analysis of harvest amount and awareness of disease effect on reported applied control using data which excluded the site of Şile.

\begin{tabular}{ccc}
\hline Factor & $t$-Value & $\operatorname{Pr}(>|t|)$ \\
\hline Harvest & 4.666 & $1.16 \mathrm{e}-05^{* * *}$ \\
Awareness & 4.397 & $3.23 \mathrm{e}-05^{* * *}$ \\
Adjusted R Squared & & 0.4639 \\
\hline
\end{tabular}

Note: ${ }^{* * *}$ indicates significant values $(p<0.001)$.

\subsection{The Results of Cluster Analysis}

Cluster analysis included site mean harvest quantity, percentage of households per site that applied control, the number of known diseases and income, and classified sites into two main groups (Figure 3). Most of the sites fall into the first group which includes two subgroups. The first subgroup consists of the sites in the eastern Black Sea region (Artvin, Trabzon and Rize) and Sile, while the second subgroup includes Zonguldak, Çanakkale and Sinop. The second main group includes the households from Aydın, İzmir and Bursa.

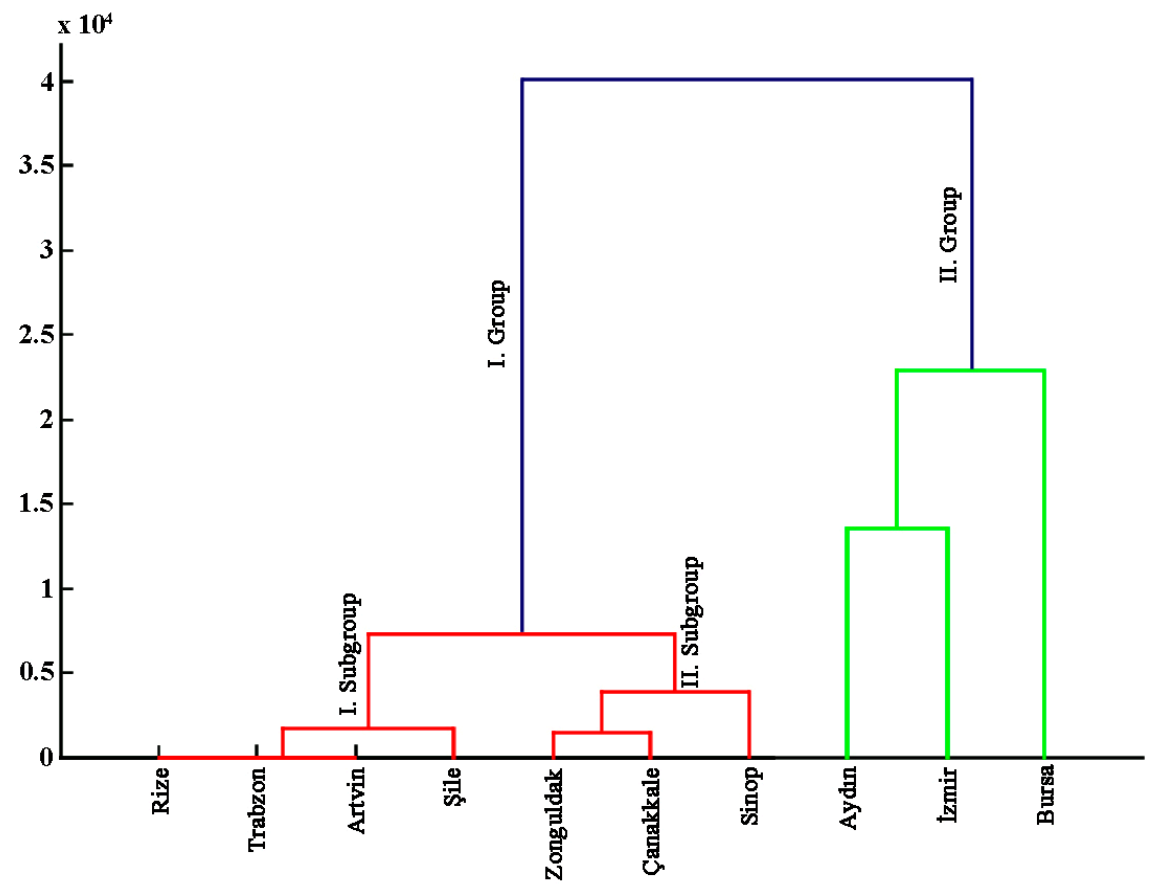

Figure 3. Dendrogram representing the results from the hierarchical cluster analysis of the sites. 


\section{Discussion}

According to interviewed households, chestnut blight was the biggest challenge to chestnut related livelihood activities (Table 1). This shows general agreement with scientific literature emphasizing that chestnut blight is the most serious threat to chestnut tree populations throughout Turkey [26-29]. However, gall wasp, which was first observed in 2014 in Yalova, Turkey [7], is now seen as a major threat as well, based on damages observed in Europe [30]. Our survey showed that awareness of gall wasp is limited but growing due to the information shared by professionals in Forest and Agricultural State Institutions in İstanbul, Bursa, Sinop, Aydın and İzmir. Yet, we observed gall wasp damages in Cumalıkızık (Bursa) and Şile (İstanbul) and heard reports of similar damage in Aydın and İzmir.

A prominent and meaningful finding is that prevention efforts of households against chestnut blight were highly correlated with production quantity (Figure 2B). For example, the least amount of harvest is from the eastern Black Sea region (Trabzon, Rize and Artvin). Here, households collect chestnuts for their domestic use (Table 3). Accordingly, it appears that this minimal value for chestnuts is related to the absence of prevention efforts in this area.

In Sile, Zonguldak and Sinop, where the mean production quantities per household are $116 \mathrm{~kg}$, $855 \mathrm{~kg}$ and $1600 \mathrm{~kg}$ respectively, households try to fight against chestnut blight by simply cutting dead and dying branches. Thus, while most villagers invest their labor in blight control, they are not inclined to invest financially. Still, there is significantly more effort when compared to sites where chestnut value is limited to home consumption. One reason for lower prevention efforts in these sites is that people consider chestnuts as an additional income (Tables 2 and 3). For example, in Şile, because of its location between two big cities, people earn money mostly from recreation and tourism activities, as well as fishery and honey production. In Zonguldak, all interviewed households derived income from local mining. The research by Chamber of Agriculture in Zonguldak stated that chestnuts provide additional income for $92 \%$ of chestnut pickers [21]. As previously mentioned and observed in contexts outside of Turkey [11], abandonment of chestnut-based livelihood activities is commonly brought about by out-migration. However, we learned that older retired participants pick chestnuts as well. While some of them benefit from children visiting during harvest time, this is not the norm.

Another reason for less management activities by villagers is that many traditional approaches to silviculture and forest sanitation are prohibited. FAO reported that villagers use trees in state forests where they are only allowed to harvest chestnuts [10]. Many villagers reported their concern that their ability to manage blight is restricted by state forest policy. For instance, many villagers argue that blight severity can be managed in rigorously coppiced systems, a practice which has been the subject of a nationwide prohibition for the last several years. Similarly, traditional silvicultural approaches to blight management include the removal of affected stems, and the clearance of vegetation, both prohibited practices in state forests. This is the result [31,32] of a 2006 decision of Ministry of Environment and Forest known as Converting of Coppice Forests to High Forests [33].

In Çanakkale, households are similar to Zonguldak and Sinop in terms of production amount (665 kg/ year per household), mostly using state forests. Chestnut sales are generally additional income for these households. Their chestnut blight management is also similar, with households simply cutting infected branches. Yet, in Çanakkale, chestnut trees in some stands in the forest were grafted but open for all households' utilization. Some of the households have their own orchards of planted and grafted chestnut trees. It is these orchard owners who use Bordeaux mixture in addition to cutting dead branches (Table 2). The owners also own apple orchards from which they have knowledge and equipment to fight the disease. These practices are transferred to chestnut orchards.

All these sites, where almost all households benefit from the state forest, fall into the first group by cluster analysis. In this main group, sites are divided into two subgroups. The first subgroup consists of the sites from the eastern Black Sea region and Şile, where production quantity is very low, and mostly for household consumption, and where almost no control is applied against chestnut blight. The second subgroup consists of Çanakkale, Sinop and Zonguldak, where production quantity 
is higher, chestnut income is additional for the households and there is little control against chestnut blight (Figure 3).

Aydın, İzmir and Bursa fall into the second group by cluster analysis associated with higher production, control and awareness. The households in Bursa harvested an average of $2595 \mathrm{~kg}$. Here, five historical Kızık villages lie in the foothills of the Uludağ Mountains. People traditionally produce chestnut. Households derive their main income from chestnut management in orchards as well as collection from grafted trees in state forests. They report two disease management methods: cutting dead branches and application of Bordeaux mixture. Bursa is a leader in grafting and nursery establishment. In our second sampling area in Bursa, Kurşunlu, chestnut production came to a halt because of severe chestnut blight disease. It was determined during the surveys and in the field observations that infected trees were removed from forests after 2006 and new grafts were established. For this reason, no actions were reported against chestnut blight.

The highest production amount was reported in Aydın and İzmir with a mean of 6350 and $6800 \mathrm{~kg}$ harvested per household, respectively. Aydın and İzmir represent almost $40 \%$ of chestnut production in Turkey [9]. While the mean production amount per household in Aydın was found to be similar to İzmir in our research, Aydın is reported as the largest producer in Turkey according to total production amount $[23,29,34,35]$. Almost all households work to mitigate chestnut blight using varying methods, including application of Bordeaux mixture, juniper tar, sodium hypochlorite, paste, mud packet and lime solution and aggressive removal of infected tissue from trunks (Table 2). This observation was also reported by FAO [10]. Here, chestnut income is the primary income for households.

Our results also showed that, excluding Sile, increasing product quantity is correlated with higher awareness of pests and diseases and the presence or absence of reported disease mitigation methods (Figure 2A,C). Şile is an outlier in our research for several reasons. First, as we have observed and documented in forthcoming research, blight severity in Sile was the highest of ten observed sites in Turkey [13]. Several additional pressures on forests and forest livelihoods were observed. Local intensive mining operations have very openly caused ecological fragmentation. Proximity to the city of İstanbul means that the town is crowded with visiting collectors during harvest time. Local forest policy has also taken a notably intensive approach with most visible forest in early succession due to regular clear cutting. Interestingly, local awareness was high which shows how the above-mentioned factors may have recently reached a critical mass for local livelihoods.

Increasing product quantity was found to be related to a higher number of reported harvesters. When the amount of harvest exceeded $2500 \mathrm{~kg}$ for a household, laborers as pickers and "Dokuyucu" (those who hit chestnuts down [36]), were hired (in Aydın, İzmir and Bursa). The wage of the "Dokuyucu" is about three times higher than that of the pickers. It is reported that this difference is due to the fact that "Dokuyucu" requires experience and is life-threatening. They wear rubber shoes to keep them from slipping and wear glasses to protect their eyes. However, they do not otherwise take any health and safety precautions. It is reported that during the harvest period, every year some "Dokuyucu" are injured, taken to hospital, and even die. For these reasons, it is stated that the number of "Dokuyucu" is small and harvest help comes from the neighboring provinces.

It has been reported that chestnuts are generally collected by the women of the family at harvest time. Households from other sites do not employ laborers, instead, less than five people including family members, relatives or neighbors harvest (Table 3). It is reported that some "Dokuyucu" are being employed in Sinop, but this is not the norm. It is reported that it is difficult to find a "Dokuyucu". However, in Sinop and Zonguldak, collecting from the forest floor without hitting chestnuts down is more common. Although FAO reported [10] that chestnuts are harvested by hitting the branches with a long stick in all areas, our research showed that it is common to pick chestnuts which naturally drop to the ground in the Black Sea region and Şile. 
Major motivations of households for chestnut harvesting include income and food value in all sites. This contrasts with the observations of Pezzi et al. from Northern Italy [11]. There, it was stated that motivations such as preserving local traditions and having a hobby were the main drivers of chestnut management by those with positive prognoses for the future of chestnut cultivation. Contrarily, income considerations had less importance for interviewees. This indicates a contrasting socioeconomic context in Turkey. However, the primacy of income potential was also a major factor in a similar study in Catalonia [12]. Our research has arrived at a similar result.

Our results showed that the most expensive chestnuts are in Sinop and Bursa, while the cheapest are in Zonguldak. Bursa's chestnuts have been famous in Turkey historically [37-39]. The region's reputation was reported in the famous travel journals of Evliya Çelebi (1611-1682) [26]. Bursa is also famous for the sweet preserved chestnut, much like the marron glacé. Despite this fame, the province of Aydın is the nation's largest producer $[23,26,29,35]$. It is thought that all these factors affect the market price of Bursa and drive up the price of its chestnuts. Chestnuts from Sinop are called "lamb chestnuts" ( $k u z u$ kestane) in Turkey and are well-known for their distinct flavor, bright color and key feature of easy detachment from the shell once roasted [40]. In addition, in Erfelek and Ayancik, chestnut markets are being set up to ensure that chestnut producers get better prices.

According to Turkish Patent and Trademark Office (TPTO), chestnuts from Aydın have had a GIP as an industrial property right since 2010 [41]. It is thought that Geographical Indication Protection will support quality control, increase recognition and add value to products derived from local chestnuts [42]. No comprehensive research has been done in this regard.

\section{Conclusions}

In this study, we presented the problems that households report are affecting their chestnut production, their awareness of pests and diseases, and their reported control efforts in Turkey. In addition, similar household perspectives were classified throughout the geographic distribution of the species. It is clear that blight control efforts increase with chestnut production and household awareness of pests and diseases. Moreover, the households that consider chestnut production as additional income and/or household consumption, harvest chestnuts with their family or friends, while the households that consider chestnut production as main income pay for laborers. High chestnut fruit prices were found to be related to branding and marketing efforts as well as fruit properties such as flavor, color and easy detachment from the shell. We believe that the results of this research will provide information to decision makers and stakeholders regarding the sustainable utilization of chestnut forests and orchards. The hopeful and natural tag-along phenomenon for the chestnut blight-hypovirulence-has been observed throughout Turkey and is thought to be naturally spreading. Therefore, understanding the dynamics of forest maintenance at all levels is presently very important. Populations that weather the present period of blight intensity may benefit at a later date from the arrival of hypovirulence only if they still exist.

Acknowledgments: The authors are highly indebted to the Republic of Turkey General Directorate of Forestry, especially their offices and personnel in Şile, Zonguldak, Borçka, Rize, Trabzon, Çanakkale, and Bursa, for their invaluable advising and support. We are also very thankful for the administration of İstanbul University Faculty of Forestry for facilitation of research efforts. We sincerely thank The Scientific and Technological Research Council of Turkey (TUBITAK), the American Research Institute of Turkey (ARIT), The U.S. Borlaug Fellows in Global Food Security Program, and the Turkish Fulbright Commission for their generous support of this research. Finally, we fully indebted to the interviewees.

Author Contributions: Taner Okan and Jeffrey Wall designed socioeconomic survey; Taner Okan and Coşkun Köse conducted the survey with households and performed data analysis. Taner Okan, Coşkun Köse and Jeffrey Wall wrote the paper.

Conflicts of Interest: The authors declare no conflict of interest. The founding sponsors had no role in the design of the study; in the collection, analyses, or interpretation of data; in the writing of the manuscript, and in the decision to publish the results. 


\section{References}

1. Xenophon. Anabasis; Wells, E.A., Ed.; Macmillan and Company Limited: London, UK, 1917.

2. De-Leonardis, W.; De-Santis, C.; Fichera, G.; Fiumara, P.M.R.; Longhitano, N.; Zizza, A. Importance of Castanea sativa Mill. in honeys of central and north-eastern Sicily on the basis of the pollen grain analysis. Ecol. Mediterr. 2000, 26, 169-175.

3. Yaltırık, F. Dendroloji Ders Kitabı II (Angiospermae); Emek Matbaacıllk: İstanbul, Turkey, 1998; pp. $118-122$.

4. Yılmaz, H. Castena Mill. In Türkiye'nin Doğal-Egzotik Ağaç ve Çalıları I; Akkemik, Ü., Yayınları, O.G.M., Eds.; MRK Baskı ve Tanıtım: Ankara, Turkey, 2014; pp. 668-669.

5. Erdem, R. Türkiye'de Kestane Ölümünün Sebepleri ve Savaş Imkanları; Tarım Bakanlığı Orman Genel Müdürlüğü Yayınları: Ankara, Turkey, 1951.

6. Akdoğan, S.; Erkam, E. Dikkat Kestane Kanseri Görüldü. Tomurcuk 1968, 1, 4-5.

7. Doğanlar, M. First reports on the natural enemy fauna of the Chesnut Gall-wasp, Dryocosmus kuriphilus Yasumatsu (Hymenoptera: Cynipidae) in Yalova, Turkey. Türk. Biyo. Müc. Derg. 2014, 5, 67-74.

8. Ak1ll, S. Feasibility of biological control of chestnut blight caused by Cryphonectria parasitica, in Marmara region of Turkey. Afr. J. Agric. Res. 2012, 7, 6068-6072.

9. Erincik, Ö.; Özdemir, Z.; Durdu, Ö.F.; Döken, M.T.; Açıkgöz, S. Diversity and spatial distribution of vegetative compatibility types and mating types of Cryphonectria parasitica in the Aydın Mountains, Turkey. Eur. J. Plant Pathol. 2011, 129, 555-566. [CrossRef]

10. FAO (Food and Agriculture Organization). Support to the Turkish Government in Development and Implementation of a Feasibility Study (FS) for Management of Chestnut Blight in Chestnuts and Other Hardwoods. Report on Chestnut Blight and Its Management in Turkey. 2009. Available online: http: / / www.fao.org/forestry/49410/en/tur/ (accessed on 23 February 2017).

11. Pezzi, G.; Lucchi, E.; Maresi, G.; Ferretti, F.; Viaggi, D.; Frascaroli, F. Abandonment or survival? Understanding the future of Castanea sativa stands in function of local attitude (Northern Apennine, Italy). Land Use Policy 2017, 61, 564-574. [CrossRef]

12. Oliva, J.; Castano, C.; Baulenas, E.; Dominguez, G.; González-Olabarria, J.R.; Oliach, D. The impact of the socioeconomic environment on the implementation of control measures against an invasive forest pathogen. For. Ecol. Manag. 2016, 380, 118-127. [CrossRef]

13. Wall, J.; Köse, C.; Okan, T.; Köse, N.; Jarvis, D.I. Evidence of Landscape-Level Chestnut Blight Severity Mitigation by Livelihood Practices in Turkey. Biol. Conserv. 2017. under review.

14. Anagnostakis, S.L. Chestnut Blight: The Classical Problem of an Introduced Pathogen. Mycologia 1987, 79, 23-37. [CrossRef]

15. Gürer, M.; Turchetti, T.; Biagioni, P.; Maresi, G. Assessment and characterization of Turkish hypovirulent isolates of Cryphonectria parasitica (Murr.) Barr. Phytopathol. Mediterr. 2001, 40, 265-275.

16. FAO (Food and Agriculture Organization). FAOSTAT. 2017. Available online: http://www.fao.org/faostat/ en/\#data/QC (accessed on 9 March 2017).

17. Akıllı, S.; Katırcıoğlu, Y.Z.; Maden, S. Vegetative compatibility types of Cryphonectria parasitica, causal agent of chestnut blight, in the Black Sea region of Turkey. For. Pathol. 2009, 39, 390-396.

18. Akıllı, S.; Ulubaş Serçe, Ç.; Katırcıoğlu, Y.Z. Characterization of hypovirulent isolates of the chestnut blight fungus, Cryphonectria parasitica from the Marmara and Black Sea regions of Turkey. Eur. J. Plant Pathol. 2013, 135, 323. [CrossRef]

19. Tandoğan, A. Türkiye Nüfus Hareketlerinde İstanbul'un Yeri. Available online: tucaum.ankara.edu.tr/wpcontent/uploads/sites/280/2015/08/cadata1_12.pdf (accessed on 15 May 2017).

20. Yakar, M. Türkiye'de iç göçlerin ilçelere göre mekânsal analizi: 1995-2000 dönemi. Uluslar. İnsan Bilim. Derg. 2012, 9, 741-768.

21. Zonguldak Chamber of Agriculture. Zonguldak Kestanesi ve Cevizine Yönelik Markalaşma Çalışmaları Projesi. 2014. Available online: http://bakkakutuphane.org/upload/dokumandosya/zonguldak-kestanesive-cevizine-yonelik-markalasma-calismalari-projesi.pdf (accessed on 3 Janaury 2017).

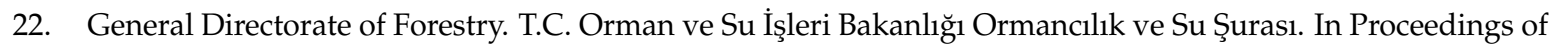
the Çalışma Grubu 10: Ormanlardan Faydalanma Şura Çalışma Belgesi, Ankara, Turkey, 21-23 March 2013. 
23. General Directorate of Forestry. Kestane Eylem Planı (2013-2017). 2012. Available online: http: //www.ogm.gov.tr/Lists/Haberler/Attachments/457/KESTANE\%20EYLEM\%20PLANI.pdf (accessed on 12 March 2017).

24. Kaya, Z.; Raynal, D.J. Biodiversity and conservation of Turkish forests. Biol. Conserv. 2001, 97, $131-141$. [CrossRef]

25. Köhn, H.-F.; Hubert, L.J. Hierarchical Cluster Analysis. In Wiley StatsRef: Statistics Reference Online; John Wiley \& Sons: Hoboken, NJ, USA, 2015; pp. 1-13.

26. Soylu, A. Chestnut Growing and Its Characteristics; Hasat Yayıncılık: İstanbul, Turkey, 2004; p. 64. (In Turkish)

27. Ertürk, Ü.; Mert, C.; Soylu, A. Chemical Composition of Fruits of Some Important Chestnut Cultivars. Braz. Arch. Biol. Technol. 2006, 49, 183-188. [CrossRef]

28. Porsuk, T.; Özyürek, E.; Karahan, A.; Başar, M.; Çetiner, Ş. Research on Socioeconomical Effects of Chestnut (Castanea Sativa Mill.) Fruit Harvesting to Forest Villager in Simav County, Kütahya Province; Technical bulletin No. 295; Central Anatolia Turkish Forestry Research Institute: Ankara, Turkey, 2012.

29. Karadeniz, V. Chestnut Agriculture in Turkey and Its main Problems. J. Int. Soc. Res. 2013, 6, $279-291$.

30. OEPP/EPPO. Dryocosmus Kuriphilus. Bulletin. 35. pp. 422-424. Available online: https://www.eppo.int/ QUARANTINE/data_sheets/insects/DS_Dryocosmus_kuriphilus.pdf (accessed on 22 March 2017).

31. Atmış, E.; Günşen, B. Türkiye'de hükümetlerin ormancılık politika ve uygulamaları üzerine eleştirel bir değerlendirme-AKP örneği. Orman ve Av Dergisi. Türk. Orman. Dern. Yayını 2009, 2, 33-42.

32. Bekiroğlu, S.; Atıc1, E.; Özkul Özer, G.; Yadigar, S.; Uslu, B. The Origins of Coppice Forests and the Socio-Economic Dimension of Conversion of Coppice Forests to High Forests (Istanbul Case). JFFIU 2013, 63, 61-70. (In Turkish).

33. General Directorate of Forestry. Baltalık Ormanlarının Koruya Dönüştürülmesi Eylem Planı (2006-2015); Çevre Orman Bakanlığı Orman Genel Müdürlüğü: Ankara, Turkey, 2006.

34. Aydın Commodity Exchange. 2013 Y1l Kestane Borsası. Available online: http://aydinticaretborsasi.org.tr/ yonetim/pdf/16112016153652u.pdf (accessed on 15 March 2017).

35. Bitkisel Üretim İstatistikleri. 2017. Available online: https://biruni.tuik.gov.tr/bitkiselapp/bitkisel.zul (accessed on 15 march 2017).

36. Okan, T.; Köse, C.; Aksoy, E.B.; Köse, N.; Wall, J.R. Traditional Terms for Sweet Chestnut (Castanea sativa Mill.) and Its Usage in Turkey. Avrasya Terim Derg. 2017, 5, 19-27.

37. Kayacık, H. Orman ve Park ă̆açlarının Özel sistematiği. Cilt II; Kurtulmuş Matbaası: İstanbul, Turkey, 1967.

38. Bozkurt, Y.; Yaltırık, F.; Özdönmez, M. Türkiye'de Orman Yan Ürünleri; İÜ Orman Fakültesi Yayınları: İstanbul, Turkey, 1982.

39. Coşkuncu, K.S.; Mert, C. Bursa, Balıkesir ve Kocaeli İlleri Kestane Üretim Alanlarında Değişik Kestane Çeşitlerindeki Meyve Kurtlanma Oranları Üzerine Araştırmalar. Karaelmas Fen Müh. Derg. 2011, 1, 31-39.

40. Topçu, K.; Serdar, U.; Öztürk, A.; Genç, M. A Chestnut Monument Tree in Sinop: Padisah Kestanesi. Acta Hort. (ISHS) 2009, 815, 163-170. [CrossRef]

41. TPTO. Aydin Kestanesi Coğrafi İşaret Tescil Belgesi. 2017. Available online: http://www.turkpatent.gov.tr/ TurkPatent/resources/temp/1A9EA479-9849-439F-BE4E-485B28F25B8E.pdf (accessed on 12 January 2017).

42. Okan, T.; Köse, C. Kırsal Kalkınma Modeli Olarak Coğrafi İşaretlerin Kullanım Olanakları ve Odun Dışı Orman Ürünleri Açısından Bir Değerlendirme. In Proceedings of the 2023'e Doğru 2. Doğa ve Ormancılık Sempozyumu, Antalya, Türkiye, 31 October-3 November 2013; pp. 201-216.

(C) 2017 by the authors. Licensee MDPI, Basel, Switzerland. This article is an open access article distributed under the terms and conditions of the Creative Commons Attribution (CC BY) license (http://creativecommons.org/licenses/by/4.0/). 